University of Nebraska - Lincoln

DigitalCommons@University of Nebraska - Lincoln

Faculty Papers and Publications in Animal

Science

Animal Science Department

July 1981

\title{
CROSSBREEDING IN SWINE: EXPERIMENTAL RESULTS
}

Rodger K. Johnson

University of Nebraska-Lincoln, rjohnson5@unl.edu

Follow this and additional works at: https://digitalcommons.unl.edu/animalscifacpub

Part of the Animal Sciences Commons

Johnson, Rodger K., "CROSSBREEDING IN SWINE: EXPERIMENTAL RESULTS" (1981). Faculty Papers and Publications in Animal Science. 81.

https://digitalcommons.unl.edu/animalscifacpub/81

This Article is brought to you for free and open access by the Animal Science Department at DigitalCommons@University of Nebraska - Lincoln. It has been accepted for inclusion in Faculty Papers and Publications in Animal Science by an authorized administrator of DigitalCommons@University of Nebraska - Lincoln. 


\title{
CROSSBREEDING IN SWINE: EXPERIMENTAL RESULTS ${ }^{1}$
}

\author{
Rodger K. Johnson ${ }^{2}$ \\ University of Nebraska, Lincoln 68583
}

\begin{abstract}
Summary
A review of recent swine crossbreeding experiments is presented and integrated with earlier work. Variation among experiments in observed heterosis for specific crosses was large for reproduction and sow productivity traits. However, standard errors of estimates were also large. It seems likely that heterosis, expressed in absolute values or in percentage units, is different for specific crosses. It is unclear whether these differences are large enough to warrant the use of unique parameter values for comparisons of alternate mating systems. In addition to average heterosis values, average direct and maternal genetic effects are given.
\end{abstract}

(Key Words: Swine, Heterosis, Crossbreeding, Breed Effects, Review.)

\section{Introduction}

The introduction of hybrid seed corn in the 1930 's, followed by its phenomenal success in commercial production, prompted swine producers to seriously consider crossbreeding. Since then, crossbreeding has become the predominant mating system employed in the production of market pigs.

Experiment station investigation into the effects of crossbreeding began in the 1980's. Otis (1904), in one of the first published reports, found that crossbreds gained better than purebreds. Excellent reviews of the early crossbreeding research have been presented by Lush et al. (1939), Craft (1953) and Fredeen (1957). Bichard and Smith (1972) provided a review of the literature for the period from 1965 to 1971 . Those authors also considered

\footnotetext{
${ }^{1}$ Published with the approval of the Directors as Paper No. 5987, Journal Ser. Nebraska Agr. Exp. Sta. Invitational paper presented at the Symposium on "Crossbreeding," held during the 71st Annu. Meet. of the ASAS, Univ. of Arizona, Tucson, July 30, 1979.

${ }^{2}$ Dept. of Anim. Sci.
}

crossbreeding within its economic context and made an attempt to predict the future value of the breeding system. They concluded that the optimum crossing system is likely to involve the use of a specialized male line on a crossbred female. The male line may be an $F_{1}$, or it may be a synthetic line partially stabilized from a crossbred base.

Understanding of the genetic basis of crossbreeding effects was enhanced by Henderson (1948), who modified the models of Sprague and Tatum (1942) to estimate general, specific and maternal combining ability and sex-linked effects. Further analytical approaches have been developed for predicting the relative merit of crossbreeding systems in terms of a few parameters (Dickerson, 1969, 1973). Sellier (1976) reviewed much of the recent European crossbreeding research and used Dickerson's approach to compare different crossing schemes.

The objectives of this report were (1) to review swine crossbreeding research reported since 1970 and conducted with breeds commonly available in the United States and (2) to integrate these results with earlier work.

\section{Materials and Methods}

Dickerson (1969) defined the mean performance of breeds and breed crosses in terms of direct and maternal average genetic effects of breeds ( $\mathrm{g}^{\mathrm{I}}$ and $\mathrm{g}^{\mathrm{M}}$ ), individual and maternal heterosis $\left(\mathrm{h}^{\mathrm{I}}\right.$ and $\left.\mathrm{h}^{\mathrm{M}}\right)$, individual and maternal recombination effects $\left(\mathrm{r}^{\mathrm{I}}\right.$ and $\left.\mathrm{r}^{\mathrm{M}}\right)$ and maternal granddam effects $\left(\mathrm{g}^{\mathrm{M} I}, \mathrm{~h}^{\mathrm{M}^{1}}\right.$ and $\left.\mathrm{r}^{\mathrm{M}^{1}}\right)$. Knowledge of these parameters for breeds and breed crosses would allow comparison of various crossing schemes, with some simplifying assumptions. For example, Dickerson (1973) expressed the fractions of heterosis, recombination loss and differential maternal and paternal performance of dam and sire breeds expected for alternative systems of breed use. Relative industry-wide efficiencies of some alternative methods of breed utilization in market pig 
production were compared, but assumed levels of performance and genetic parameters were used.

The importance of recombination loss in pigs has not been shown experimentally. However, estimates of the other parameters can be obtained from recent crossbreeding experiments. Experiments conducted in Iowa (Bereskin et al., 1971; Schneider, 1978), Oklahoma (Young et al., 1976a,b; Johnson et al., 1978; E. R. Wilson and R. K. Johnson, unpublished manuscript; L. K. Hutchens and R. K. Johnson, unpublisbed data), Canada (Fahmy et al., 1971; Dufour and Fahmy, 1975), Wisconsin (Kuhlers et al., 1972, 1977) and North Carolina (Nelson and Robison, 1976a) had similar designs and several breeds in common. Means from these experiments were used for the estimation of breed and heterosis effects (Johnson, 1980).

It is virtually impossible to experimentally compare all possible crossing schemes with all breeds presently available. Computer simulation allows comparison of systems, but to be useful. accurate estimates of differences in genetic parameters among specific crosses are necessary. In this paper, an attempt is made to determine whether heterosis is breed-cross specific. Also, specific estimates of direct and maternal genetic breed effects are compared and overall averages presented. The limited information on crossbred males is presented and discussed.

\section{Results}

\section{Individual Heterosis}

Reproduction. Estimates of individual heterosis for specific breed crosses for reproductive performance are presented in table 1 . All of the estimates for age at puberty are negative. Although there was little overlap in the breeds involved, recent estimates of heterosis for age at puberty ( $L$. K. Hutchens and R. K. Johnson, unpublisbed data) are lower than earlier estimates (Foote et al., 1956; Zimmerman et al., 1960; Clark et al., 1970). Averaged over all experiments, crossbreds were 14.3 days younger at puberty than purebreds.

Heterosis estimates for conception rate have been quite variable, ranging from -5.8 to $7.2 \%$ (Johnson et al., 1978) and from -6.2 to $10.9 \%$ (Schneider, 1978). In the two experiments, a total of 1,481 females was measured, but specific estimates had large standard errors.
Crossbred females averaged 1.8 and $3.8 \%$ higher conception rates than purebreds. Although a mean value was not presented, European workers also found improved fertility of crossbred females (Sellier, 1976).

Johnson et al. (1978) found very little difference between purebred and crossbred gilts in ovulation rate. The lack of heterosis and the relatively high realized heritability $(.42 \pm$ .06) reported by Cunningham et al. (1979) suggest that genetic variation for ovulation rate is primarily additive. Squires et al. (1952), however, reported significantly more ova per gilt for crosses among inbred lines than for pure lines.

Estimates of individual heterosis for number of embryos and litter size provide little evidence that crossbreds have higher livability from conception to birth than purebreds. No estimate of individual heterosis for number of embryos was significant and the estimate of $1.25 \pm .38$ pigs/litter for Duroc-Yorkshire (Young et al., 1976a) was the only significant value for litter size at birth. Young et al. (1976a) and Schneider (1978) provided independent estimates of individual heterosis for crosses among Duroc, Hampshire and Yorkshire. These estimates do not agree closely, particularly those for DurocYorkshire crosses. Averaged overall, heterosis estimates for litter size at birth were $.38 \pm .26$ pigs (Young et al., 1976a), $-.29 \pm .19$ pigs (Schneider, 1978), .62 \pm .54 pigs (E. R. Wilson and R. K. Johnson, unpublished manuscript) and $.23 \pm .36$ pigs (L. K. Hutchens and R. K. Johnson, unpublisbed data).

Individual heterosis is important for postfarrowing survival. Estimates for litter size at 21 days were consistent in the experiments reported by Young et al. (1976a) and Schneider (1978), except those for Duroc-Yorkshire and Hampshire-Yorkshire crosses. These discrepancies were related to the differences observed for litter size at birth. In all cases, except DurocYorkshire in the experiment of Young et al. (1976a), individual heterosis estimates were higher for litter size at 21 days than for litter size at birth, which provides evidence of important heterosis effects on pig survival. In the four experiments, mean heterosis values for litter size at 21 days (42 days for Duroc-LandraceSpot-Yorkshire crosses; L. K. Hutchens and R. K. Johnson, unpublished data) were: .65 \pm .23 (Young et al., 1976a), .23 \pm .17 (Schneider, 1978), $1.04 \pm .48$ (E. R. Wilson and R. K. Johnson, unpublisbed manuscript) and $.90 \pm$ 


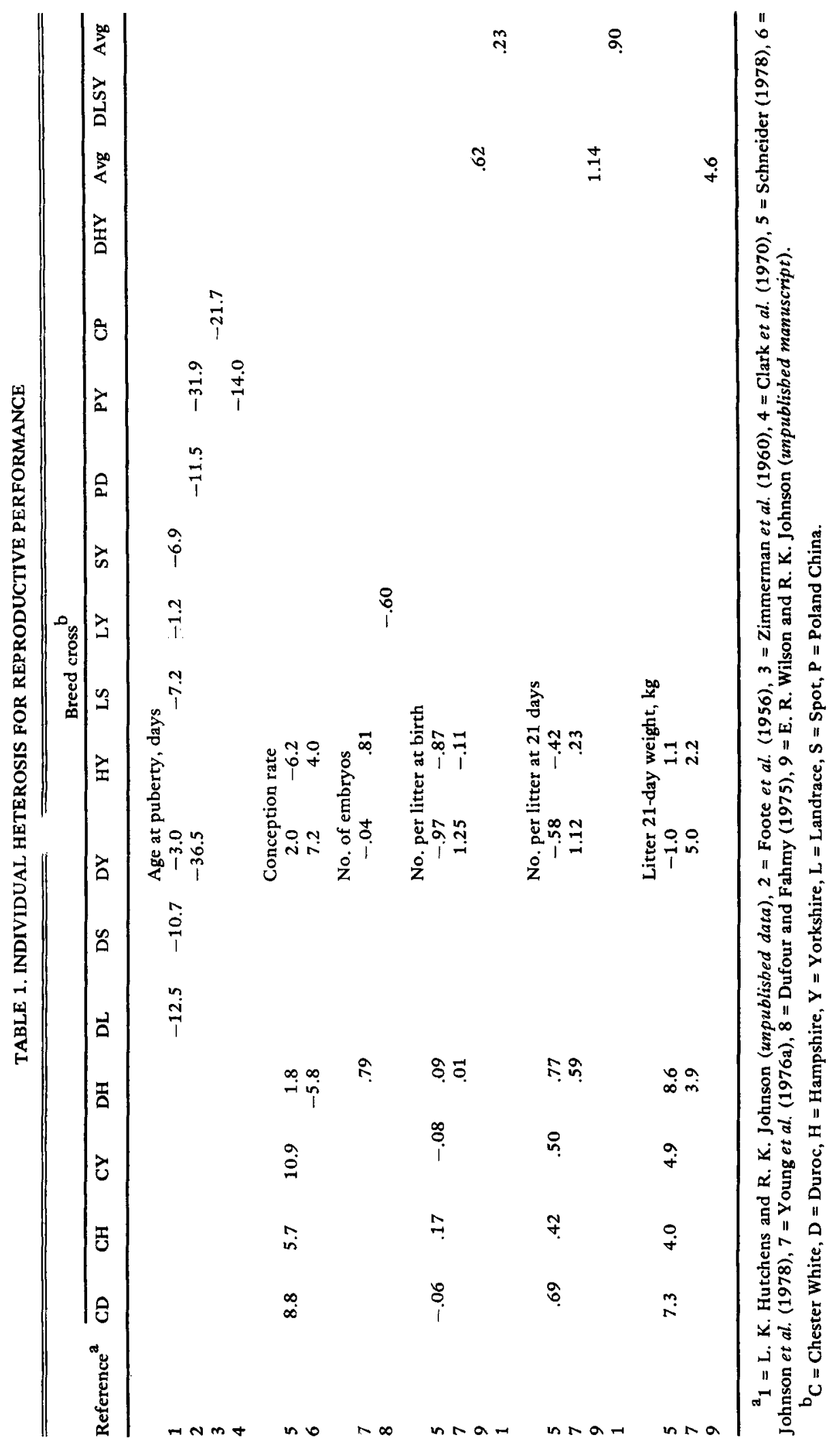


.32 (L. K. Hutchens and R. K. Johnson, unpublisbed data).

Individual heterosis estimates for litter 21-day weight were also variable. But some of the variation resulted because the same crosses provided different estimates in different experiments, e.g., Duroc-Hampshire and DurocYorkshire crosses. Also, estimates of heterosis for Hampshire-Yorkshire crosses were low (Young et al., 1976a; Schneider, 1978). However, mean heterosis estimates were consistent: $4.2 \pm 1.0 \mathrm{~kg}$ (Schneider, 1978), $3.7 \pm 1.1 \mathrm{~kg}$ (Young et al., 1976a) and $4.6 \pm 2.4 \mathrm{~kg}$ (E. R. Wilson and R. K. Johnson, unpublisbed manuscript).

Growth. Estimates of individual heterosis for pig weights, postweaning growth and food conversion are shown in table 2. Individual heterosis effects on pig weight at birth and 21 days were reasonably consistent across the three experiments. Heterosis effects on pig birth weight averaged $.06 \pm .01 \mathrm{~kg}$ (Schneider, 1978), .01 $\pm .02 \mathrm{~kg}$ (Young et al., 1976a) and $.04 \pm .04 \mathrm{~kg}$ (E. R. Wilson and R. K. Johnson, unpublisbed manuscript). Estimates of heterosis values for 21-day weight were variable. Mean values were $.36 \pm .06 \mathrm{~kg}$ (Schneider, 1978), .16 $\pm .09 \mathrm{~kg}$ (Young et al., 1976a) and $-.04 \pm .18$ kg (E. R. Wilson and R. K. Johnson, unpublisbed manuscript). There was an inverse relationship between mean heterosis for litter size and pig weight. Perhaps heterosis effects on 21-day weight would be larger and more consistent if adjustments were made for litter size.

Individual heterosis estimates for postweaning growth and food conversion were similar for all crosses evaluated for all experiments. Specific estimates of heterosis for average daily gain ranged from .04 to .09 $\mathrm{kg} /$ day and most estimates were between .05 and $.08 \mathrm{~kg} /$ day. Nearly all estimates were significant. Mean heterosis for the experiments ranged from .05 to $.07 \mathrm{~kg} / \mathrm{day}$.

Heterosis estimates for postweaning food conversion $(G: F)$ were positive for all crosses. Nonsignificant estimates were reported by Kuhlers et al. $(1972,1977)$. However significant estimates of heterosis for food conversion were reported by $\mathbf{E}$. R. Wilson and R. K. Johnson (unpublisbed manuscript) and Young et al. (1976b).

Carcass Merit. Generally, individual heterosis

TABLE 2. INDIVIDUAL HETEROSIS: FOR GROWTH TRAITS

\begin{tabular}{|c|c|c|c|c|c|c|c|c|c|c|c|c|c|}
\hline \multirow[b]{2}{*}{ Reference $^{\mathbf{a}}$} & \multicolumn{13}{|c|}{ Breed cross ${ }^{b}$} \\
\hline & CD & $\mathrm{CH}$ & CY & $\mathrm{DH}$ & DL & DS & DY & $\mathrm{HY}$ & LS & LY & SY & PY & DHY Avg. \\
\hline \multicolumn{14}{|c|}{ Birth weight, lkg } \\
\hline 1 & .09 & .03 & .05 & .03 & & & .04 & .09 & & & & & \multirow[b]{3}{*}{.04} \\
\hline 2 & & & & .06 & & & -.05 & .03 & & & & & \\
\hline 3 & & & & & & & & & & & & & \\
\hline \multicolumn{14}{|c|}{ 21-day weight, kg } \\
\hline 1 & .42 & .29 & .20 & .55 & & & .22 & .49 & & & & & \\
\hline 2 & & & & .25 & & & .07 & .14 & & & & & \\
\hline 3 & & & & & & & & & & & & & -.04 \\
\hline \multicolumn{14}{|c|}{ Postweaning gain, kg/day } \\
\hline 1 & .07 & .06 & .06 & .06 & & & .08 & .08 & & & & & \multirow{4}{*}{.05} \\
\hline 3 & & & & & & & & & & & & & \\
\hline 4 & & & & .06 & & & .06 & .04 & & & & & \\
\hline 5 & & & & & .07 & .09 & .09 & & .05 & .05 & .05 & & \\
\hline 6 & & & & & & & & & & & & .04 & \\
\hline \multirow[t]{2}{*}{7} & & & & & & & & & & & & .07 & \\
\hline & & \multicolumn{12}{|c|}{ Postweaning food conversion, gain/feed } \\
\hline 3 & & & & & & & & & & & & & .02 \\
\hline 4 & & & & .010 & & & .009 & .031 & & & & & \\
\hline 6 & & & & & & & & & & & & .02 & \\
\hline 7 & & & & & & & & & & & & .02 & \\
\hline
\end{tabular}

\footnotetext{
$\mathrm{a}_{1}=$ Schneider (1978), 2 = Young et al. (1976a), $3=\mathrm{E}$. R. Wilson and R. K. Johnson (unpublisbed manuscript), 4 = Young et al. (1976b), $5=\mathrm{L}$. K. Hutchens and R. K. Johnson (unpublisbed data), $6=$ Kuhlers $e t$ al. (1972), 7 = Kuhlers et al. (1977).

${ }^{\mathrm{b}} \mathrm{C}=$ Chester White, $\mathrm{D}=$ Duroc, $\mathrm{H}=$ Hampshire, $\mathrm{Y}=$ Yorkshire, $\mathrm{L}=$ Landrace, $\mathrm{S}=\mathrm{Spot}, \mathrm{P}=$ Poland China.
} 
estimates for carcass measurements have been small and not significantly different from zero (table 3). Estimates for carcass quality (Young et al., 1976b; Schneider, 1978) have been inconsistent (table 4). Because different scoring systems were used in the two experiments cited, only percentage values are shown. Few estimates were significant; however, estimates for muscle color were consistently negative and averaged $-4.1 \%$ across the two experiments.

General. Average individual heterosis values, expressed in units of measurement and as a percentage of the mean, are presented in table 5. In many instances, estimates from the present study were larger than, but in agreement with, those reported by Sellier (1976). They were also somewhat larger than those estimated from weighted least-squares analyses (Johnson, 1980 ) in which data from the same experiments were used. However, after those analyses were completed, additional data were obtained from two experiments, and they are included in the averages presented here.

It is difficult to determine whether heterosis, particularly heterosis for reproductive traits, is different for specific crosses or whether overall mean heterosis values can appropriately be used for comparing mating systems. In an attempt to answer this question, Johnson (1980) analyzed the breed cross means for experiments that included both purebred and crossbred litters from purebred dams. For reproductive traits, the model included the effects of experiment, breed of dam and heterosis (crossbred versus purebred). Weighted least-squares procedures were used whereby each mean was weighted by the number of observations in the mean. Residual mean squares were compared to a literature average of within-breed variances. Since the model tested only for average heterosis, interactions of heterosis by experiment and heterosis by breed-cross would have inflated the residual mean square. Unfortunately, these interactions could not be separated from those caused by breed of dam $x$ experiment interactions.

Residual mean squares from those analyses are compared to literature estimates of variance in table 6. Perhaps there is some evidence to suggest variation in individual heterosis for litter size at 21 days and for conception rate.

Sellier (1976) discussed possible explanations for observed variation in heterosis estimates. Genetic diversity among parental breeds (specific combining ability among pairs of breeds) and intrinsic factors were considered. Observed heterosis may also vary, depending on the genetic diversity of the sample of the breeds obtained for each experiment.

As described in each experiment reported, management regimens were reasonably similar, and Schneider (1978) found little evidence of a parity $x$ heterosis interaction for sow productivity traits. Inspection of the mean heterosis values for specific crosses in different experiments indicates that a plausible explanation for the interaction is the wide variation in heterosis expressed by a specific cross. In most cases, it seems reasonable to use average heterosis values to differentiate among crossing systems. Sellier (1976), however, observed that direct heterosis effects were generally larger in HampshireDuroc, Yorkshire-Duroc and Hampshire-Yorkshire combinations than in Landrace-Large White (Yorkshire) crosses.

\section{Maternal Heterosis}

Reproduction. The superiority of crossbred females to purebreds is evident from the estimates of maternal heterosis for number of embryos 30 days postbreeding, litter size, pig weight and litter weight (table 7). Again, there is much variation among specific estimates. Duroc-Hampshire crosses gave the lowest estimate for litter size when measured 30 days postbreeding but yielded a relatively high value when measured at birth or 21 days of age. Johnson et al. (1978) reported low values for maternal heterosis effects on litter size at birth for Duroc-Yorkshire females and a high value for Hampshire-Yorkshire crosses. Both estimates had large standard errors. Also, Schneider (1978) found no evidence that maternal heterosis for litter size was different among the crosses evaluated, and he reported only the overall average. In the two experiments cited, maternal heterosis estimates were almost identical for litter size at birth, but Johnson et al. (1978) reported an estimate about twice as large as that reported by Schneider (1978) for litter size at 21 days.

Estimates from the two studies of maternal heterosis effects on pig weight at birth and 21 days were generally small and variable. These were difficult to interpret because crossbred females were raising more pigs. The small estimate for 21-day weight may be interpreted as a sign of important maternal heterosis effects, since crossbred dams were raising more 


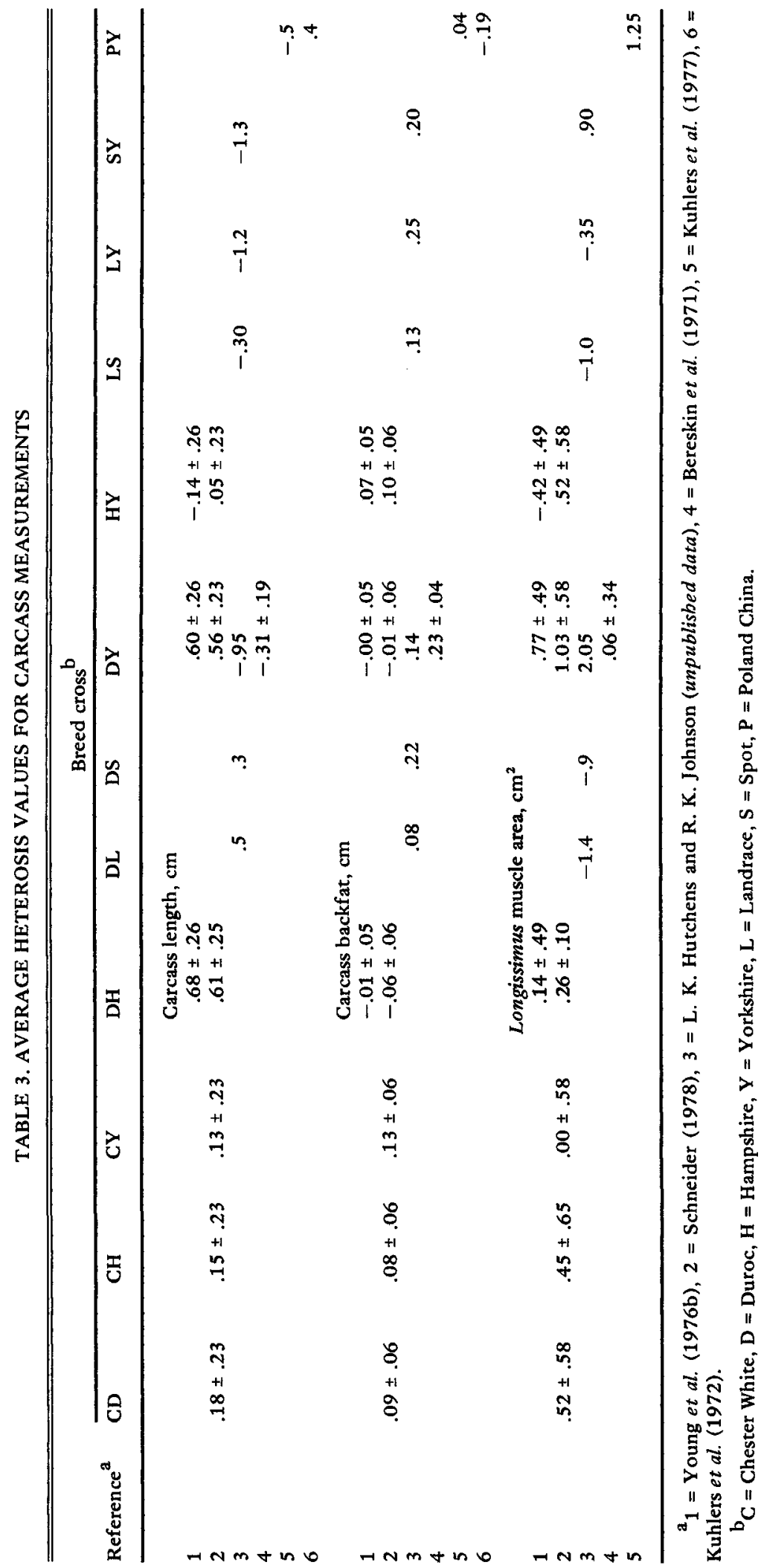


TABLE 4. AVERAGE PERCENTAGE HETEROSIS VALUES FOR IARCASS QUALITY

\begin{tabular}{|c|c|c|c|c|}
\hline \multirow[b]{2}{*}{ Breed cross ${ }^{a}$} & \multicolumn{2}{|c|}{ Individual } & \multicolumn{2}{|c|}{ Maternal } \\
\hline & $1^{b}$ & $2^{6}$ & $3^{b}$ & $2^{6}$ \\
\hline \multicolumn{5}{|c|}{ Marbling score } \\
\hline $\mathrm{CD}$ & & -.1 & & \\
\hline $\mathrm{CH}$ & & -6.1 & & \\
\hline CY & & .6 & & \\
\hline DH & $10.8^{*}$ & -1.0 & -3.1 & \\
\hline DY & 6.3 & -4.6 & -1.9 & \\
\hline HY & -9.9 & -5.1 & -1.3 & \\
\hline Avg & 3.6 & -2.7 & -2.1 & -.8 \\
\hline \multicolumn{5}{|c|}{ Firmness score } \\
\hline \multicolumn{5}{|c|}{ - } \\
\hline $\mathrm{CH}$ & & . & & \\
\hline \multicolumn{5}{|l|}{ CY } \\
\hline DH & 6.4 & & -6.6 & \\
\hline DY & 3.3 & & -7.5 & \\
\hline HY & -6.9 & & .6 & \\
\hline Avg & .9 & & -4.5 & \\
\hline \multicolumn{5}{|c|}{ Color score } \\
\hline $\mathrm{CD}$ & & -4.0 & & \\
\hline $\mathrm{CH}$ & & $-10.2^{*}$ & & \\
\hline CY & & 1.3 & & \\
\hline DH & .6 & $-4.7^{\bullet}$ & -3.4 & \\
\hline DY & -.4 & -2.9 & 1.7 & \\
\hline HY & $-11.0^{*}$ & $-6.5^{*}$ & -5.7 & \\
\hline Avg & -3.6 & -4.4 & -2.5 & -.7 \\
\hline
\end{tabular}

${ }^{\mathrm{a}} \mathrm{C}=$ Chester White, $\mathrm{D}=$ Duroc, $\mathrm{H}=$ Hampshire, $\mathbf{Y}=$ Yorkshire.

$\mathrm{b}_{1}=$ Young et al. (1976b), 2 = Schneider (1978), $3=$ Johnson et al. (1978).

${ }^{*} \mathrm{P}<.05$.

pigs to the same average weight as-or to a higher average weight than-purebreds. Maternal heterosis estimates for litter 21-day weight were consistent, and similar averages were obtained in both experiments.

Weighted least-squares analyses completed on means from these experiments (Johnson, 1980) yielded the residual mean squares presented in table 6 . In comparison to within-breed variances, only the residual mean square for pig birth weight was large enough to suggest interactions among effects in the model.

Postweaning Performance and Carcass Merit. Average maternal heterosis values for postweaning performance and carcass merit are presented in table 8 . Estimates are small and suggest that maternal heterosis effects are unimportant beyond weaning.
General. Average maternal heterosis values from this study and from the study by Sellier (1976) are reported in table 9. These agree closely. Average values appear to be appropriate for comparing alternate mating systems. Also, differences between reciprocal cross females have not been significant (Johnson et al., 1978), even though maternal effects on reproduction associated with size of the litter in which a dam was reared have reported (Nelson and Robison, 1976b). Earlier estimates of the superiority of crossbred sows ranged from 0 to 1.2 pigs (Winters et al., 1935; Robison, 1948; Chambers and Whatley, 1951; Bradford et al., 1953, Whatley et al., 1954; Smith and McLaren, 1967).

\section{Breed Effects \\ Conception Rate. Least-squares constants for} conception rate (Johnson, 1980) for eight breeds from several experiments are presented in table 10. Breed effects were significant; they were 8.2 and $8.5 \%$ above average for Chester White, Hampshire and Berkshire and 6.3 to $8.5 \%$ below average for Yorkshire, Landrace and Large Black. Numbers were not large for some breeds, but differences among Duroc, Hampshire and Yorkshire were consistent in the various experiments.

Ovulation Rate. Few breeds have been characterized for ovulation rate. Young et al. (1976a) reported ovulation rates of $14.05,12.41$ and 13.89 for Duroc, Hampshire and Yorkshire, respectively. Johnson et al. (1978) compared purebred and crossbred females. Daughters of Duroc sires had $.84 \pm .35$ and $.28 \pm .33$ more corpora lutea than daughters of Hampshire and Yorkshire sires, respectively. Dufour and Fahmy (1975) reported that Yorkshire and Lacombe sows each averaged 14.1 corpora lutea, which was one fewer than Landrace.

Litter Traits. Johnson (1980) included breedcross means from experiments that involved purebred dams mated to produce crossbred litters in weighted least-squares analyses that included the effects of experiment and breed of dam. Residual mean squares were 11.2, 6.03, .13 and 19.3 for number born per litter, number weaned per litter, pig birth weight and pig weaning weight, respectively. Except for number weaned per litter, these values were larger than within-breed variances (table 10). Differences among breeds of dam were not the same in each experiment; however, breeds 
TABLE 5. AVERAGE INDIVIDUAL HETEROSIS VALUES

\begin{tabular}{|c|c|c|c|c|}
\hline \multirow[b]{2}{*}{ Trait } & \multirow[b]{2}{*}{ Mean } & \multirow[b]{2}{*}{$\%$} & \multicolumn{2}{|c|}{ Se!lier (1976) } \\
\hline & & & Mean & $\%$ \\
\hline \multicolumn{5}{|l|}{ Reproduction $^{2}$} \\
\hline $\mathbf{C R}, \%$ & 2.80 & 3.5 & & \\
\hline OR & .04 & .3 & & \\
\hline NE & -.04 & -.1 & & \\
\hline LSB & .23 & 2.4 & $.30_{h}$ & 3 \\
\hline LS21 & .70 & 10.2 & $.45^{\circ}$ & $6^{D}$ \\
\hline PWB, kg & .04 & 2.6 & & \\
\hline PW21, kg & .16 & 2.8 & $.50_{\mathrm{b}}^{\mathrm{b}}$ & $5_{h}^{b}$ \\
\hline LW21, $\mathbf{k g}$ & 4.20 & 12.0 & $9.00^{\mathrm{b}}$ & $12^{b}$ \\
\hline \multicolumn{5}{|l|}{ Growth } \\
\hline Avg daily gain, $\mathbf{k g}$ & .06 & 8.8 & .04 & 6 \\
\hline Days to $100 \mathrm{~kg}$ & -12.70 & -6.9 & -10.00 & -5 \\
\hline Gain: feed & .017 & 5.9 & $-.08^{\mathrm{c}}$ & $-3^{c}$ \\
\hline \multicolumn{5}{|l|}{ Carcass } \\
\hline Length, cm & .00 & .0 & & \\
\hline Backfat, cm & .04 & 1.3 & & \\
\hline Longissimus area, $\mathrm{cm}^{2}$ & .23 & .8 & & \\
\hline Marbling & & .5 & & \\
\hline Firmness & & 1.5 & & \\
\hline Color & & -4.1 & & \\
\hline
\end{tabular}

${ }^{a} \mathrm{CR}=$ conception rate $; \mathrm{OR}=$ ovulation rate; $\mathrm{NE}=$ number of embryos; $L S=$ litter size; $\mathrm{B}=$ birth, $21=21$ days; $P W=$ pig weight $; \quad L W=$ litter weight.

${ }^{b}$ Weaning age varied among experiments.

Feed:gain.

tended to rank similarly. Least-squares constants and standard errors for breed of dam effects are presented in table 10 .

Breeds ranked about the same for litter size at birth and weaning. Chester White, Lacombe and Yorkshire consistently ranked high for litter size, while Berkshire, Hampshire, Large Black and Spot were below average.

Differences among breeds of dam were not as consistent for average pig weight per litter. The correlation between litter size at birth and pig birth weight was -.56 and that between litter size at weaning (age varied from 42 to 56 days) and pig weaning weight was -.62 . In most experiments, pigs were given creep feed at 21 days of age. There was much variation among experiments in the ranking of breeds for pig weight. This variation may be due to the use of different management regimens and makes interpretation of overall averages difficult.

Considering litter size as a trait of the dam plus the heterosis expressed by the pigs (assumed to be similar for all crosses), least-squares constants in table 10 estimate the sum of the direct and maternal genetic effects of the breeds. In table 11 , estimates of general combining ability and maternal effects (Schneider, 1978) and estimates of direct and maternal genetic effects (E. R. Wilson and R. K. Johnson, unpublished manuscript) are compared with the

TABLE 6. RESIDUAL MEAN SQUARES

(JOHNSON, 1980) COMPARED TO LITERATURE ESTIMATES OF VARIANCE

\begin{tabular}{lrcc}
\hline Trait & \multicolumn{1}{c}{ MS $^{\mathrm{a}}$} & $\mathrm{MS}^{\mathrm{b}}$ & $\hat{\sigma}^{2}$ \\
\hline Conception rate, \% & $2,836.20$ & & $1,476.0^{\mathrm{c}}$ \\
Litter size, birth & 9.50 & 5.5 & 8.2 \\
Litter size, 21 days & 13.80 & 7.2 & 6.1 \\
Pig birth weight, kg & .07 & .13 & .044 \\
Pig 21-day weight, kg & .77 & 1.18 & .77 \\
\hline
\end{tabular}

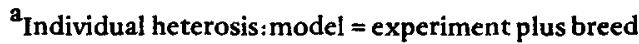
of dam plus heterosis.

b $_{\text {Maternal heterosis: } \text { model }}=$ experiment plus breed of purebred dam plus breed cross of crossbred dam plus heterosis.

${ }^{c}$ Estimated on the basis of mean of $\mathbf{8 2 \%}$. 
TABLE 7. AVERAGE MATERNAL HETEROSIS FOR SEVERAL TRAITS

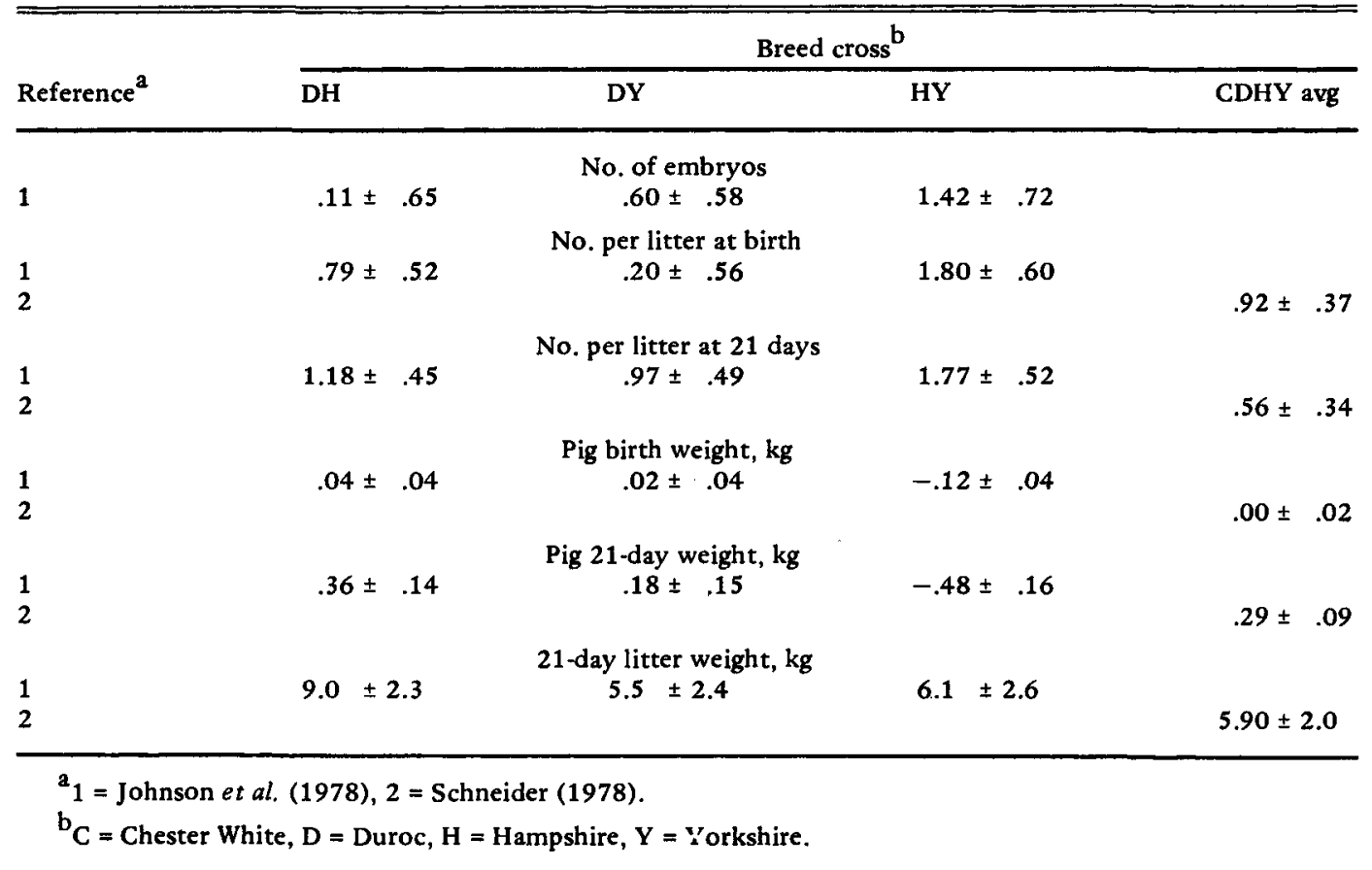

least-squares constants. General combining ability was not significant (Schneider, 1978), but E. R. Wilson and R. K. Johnson (unpublisbed manuscript) found significant differences among Duroc, Hampshire and Yorkshire in direct genetic effects on litter size weaned. Both investigations showed significant differences among the breeds in maternal ability.

General combining ability (GCA) was defined by Schneider (1978) as being equivalent to breed of sire effects estimated from single crosses only. He computed maternal ability as the breed of dam effect estimated from single crosses only minus the GCA for the breeds.

For Duroc, Hampshire and Yorkshire, estimates of GCA (Schneider, 1978) and the direct effect of the breed, $g^{I}$ (E. R. Wilson and R. K. Johnson, unpublished manuscript) are different. On the other hand, estimates of maternal effects agree quite well. Also, the sum of direct plus maternal effects from each study would provide a ranking of the breeds similar to the ranking obtained from the weighted least-squares analysis.

Growth. The weighted least-squares analyses (Johnson, 1980) included the effects of experiment, breed of sire, breed of dam and purebreds versus crossbreds. Residual mean squares for average daily gain (.025) and days to $100 \mathrm{~kg}$ $(1,102)$ were larger than within-breed variances reported in the literature (.0045 and 225, respectively). This may be explained in part by

TABLE 8. AVERAGE MATERNAL HETEROSIS VALUES FOR POSTWEANING PERFORMANCE AND CARCASS MERIT

\begin{tabular}{lllllll}
\hline & \multicolumn{1}{c}{ Trait } \\
\cline { 2 - 7 } Reference & $\begin{array}{l}\text { Avg daily } \\
\text { gain, } \mathrm{kg}\end{array}$ & $\begin{array}{l}\text { Days to } \\
100 \mathrm{~kg}\end{array}$ & Gain:feed & $\begin{array}{l}\text { Carcass } \\
\text { length, cm }\end{array}$ & $\begin{array}{l}\text { Carcass } \\
\text { backfat, cm }\end{array}$ & $\begin{array}{l}\text { Longissimus } \\
\text { area, } \mathrm{cm}^{2}\end{array}$ \\
\hline Johnson et al. (1978) & $.00 \pm .01$ & $-.4 \pm .9$ & $-.00 \pm .003$ & $.00 \pm .2$ & $.07 \pm .04$ & $.7 \pm .3$ \\
Schneider (1978) & $-.01 \pm .01$ & $1.2 \pm 1.8$ & & $.03 \pm .2$ & $.00 \pm .05$ & $0 \pm .5$ \\
\hline
\end{tabular}


TABLE 9. AVERAGE MATERNAL HETEROSIS VALUES FOR REPRODUCTION TRAITS

\begin{tabular}{lcrlll}
\hline & \multicolumn{2}{c}{ Present study } & & \multicolumn{2}{c}{ Sellier (1976) } \\
\cline { 2 - 3 } \cline { 5 - 6 } Trait $^{2}$ & Absolute & $\%$ & & Absolute & $\%$ \\
\hline NE & .71 & 4.4 & & \\
LSB & .93 & 9.9 & & .75 & $8.0^{b}$ \\
LS21 & .93 & 13.0 & & $.85^{b}$ & $11.0^{b}$ \\
PWB, kg & -.01 & -.7 & & \\
PW21, kg & .15 & 2.8 & & .0 & 0 \\
LW21, kg & 6.40 & 16.7 & & $8.0^{b}$ & $10.0^{b}$ \\
\hline
\end{tabular}

${ }^{\mathrm{a}} \mathrm{NE}=$ number of embryos; LS = litter size; $\mathrm{B}=$ birth; $21=21$ days; $\mathrm{PW}=$ pig weight; LW $=$ litter weight.

${ }^{b}$ Weaning age varied among experiments.

the fact that growth was measured over different age and weight intervals. The differences may also reflect average genetic differences among breed samples. These appear to be differences in magnitude rather than rank, as breeds and crosses ranked similarly in most experiments.

Breed of sire and breed of dam effects were significant for growth rate (table 12). Durocsired pigs gained $.02 \mathrm{~kg} /$ day faster and reached market weight 3.2 days sooner than average. In contrast, pigs by Chester White sires gained .03 $\mathrm{kg} / \mathrm{day}$ less and were 7.7 days older than average at 100 kilograms. Pigs of other sire breeds were similar in growth. Breed of dam differences were similar to breed of sire effects. The correlation coefficient between breed of dam and breed of sire effects for average daily gain was .90 . Breed of sire effects estimate one-half the average direct genetic effect of the breed, while breed of dam effects include one-half the direct effect plus the maternal effect. These data gave little evidence of breed differences in maternal genetic effects. Thus, it is useful to add the constants for breed of sire and breed of dam to estimate differences among breeds in direct genetic effects.

These estimates are biased if maternal genetic differences among breeds are important or if specific heterosis differs among breed crosses. Heterosis was similar for all crosses (table 2). E. R. Wilson and R. K. Johnson (unpublisbed manuscript) estimated direct and maternal genetic effects from data on 1,242 purebred, two-breed cross, three-breed cross and backcross litters, and Schneider (1978) estimated general combining ability and maternal ability from
1,065 purebred, single cross and backcross litters. Estimates are presented in table 13. Maternal effects were not significant in either experiment. Differences among breeds in direct effects and general combining ability were similar and in reasonable agreement with the summed effects presented in table 12.

Insufficient data were available for comparing breeds averaged over experiments for food conversion. Young et al. (1976b) found significant breed of sire and breed of dam effects. Hampshire-sired pigs were more efficient than Duroc- or Yorkshire-sired pigs; however, pigs out of Yorkshire dams were more efficient than pigs out of Duroc or Hampshire dams. Similar differences were found by Johnson et al. (1978). Large differences in reciprocal crosses involving Yorkshire were evident and indicate important breed maternal effects. These are discussed in more detail below.

Carcass Traits. Johnson (1980) analyzed carcass trait means from experiments involving purebred and crossbred matings, using a model that included the effects of experiment, breed of sire, breed of dam and heterosis. Residual mean squares for each carcass trait were larger than literature estimates of trait variances. This may have been due to significant interactions among effects in the model or failure to use the correct model. Significant differences between reciprocal crosses have been reported (Bereskin et al., 1971; Young et al., 1976b). Also, differences among breed samples would contribute to experiment $x$ breed interactions. There was some evidence of an interaction, as breed differences were not the same in each experiment. In some cases, there were also large reciprocal differences.

Breed of dam and breed of sire effects were not the same for carcass traits (table 14). Correlation coefficients between breed of sire and dam effects were $.60, .36$ and .33 for length, backfat and longissimus muscle area, respectively. This finding indicates the presence of maternal effects.

Perhaps the most useful estimate of average direct genetic effects for the breeds can be obtained by doubling the breed of sire effects. Average maternal effects can then be estimated by the difference between breed of dam and breed of sire effects. These values were calculated and are presented in table 15. Direct genetic effects for Hampshire, Landrace and Yorkshire were well above average for carcass length, whereas Spot and Poland were well 


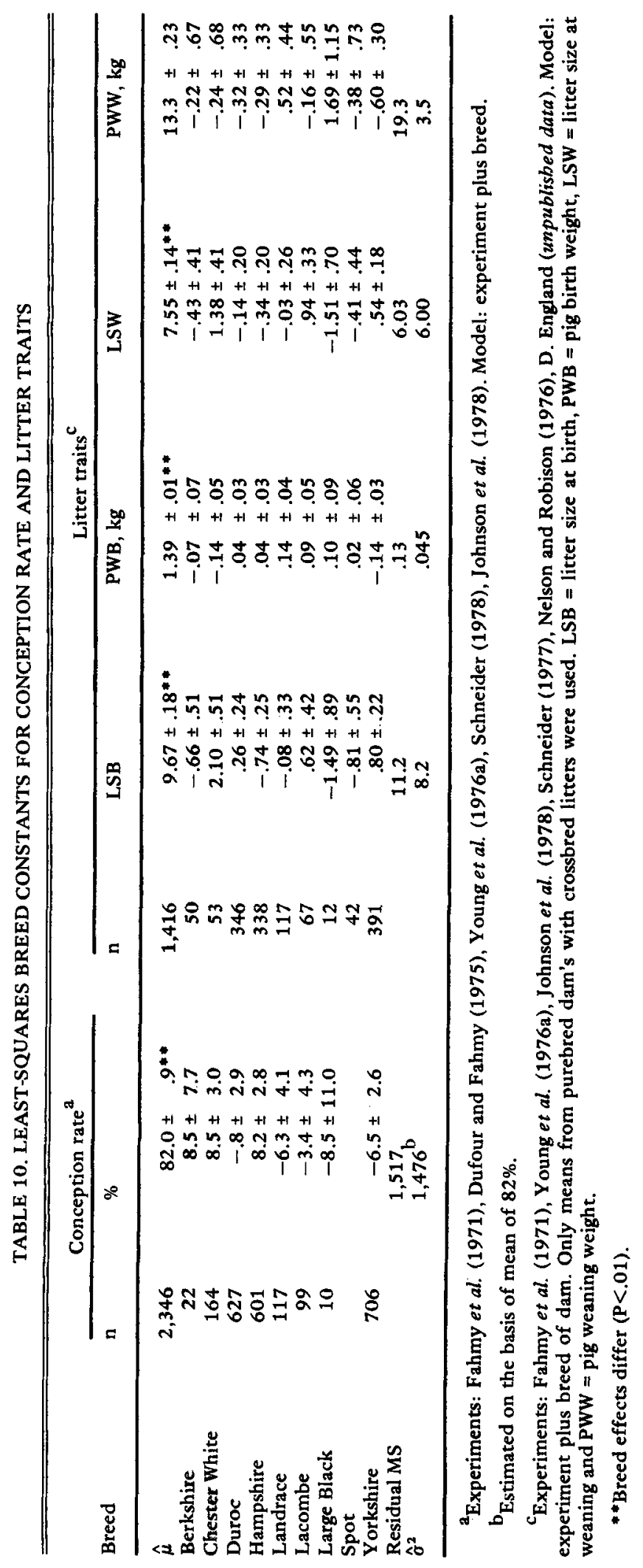


TABLE 11. LEAST-SQUARES BREED ESTIMATES OF LITTER SIZE WEANED ( $\hat{\alpha})$ COMPARED TO ESTIMATES OF GENERAL COMBINING ABILITY (GCA), DIRECT GENETIC (g ${ }^{\mathrm{I}}$ ) AND MATERNAL EFFECTS $\left(\mathrm{g}^{\mathrm{M}}\right)$

\begin{tabular}{lccccc}
\hline Breed & $\hat{\alpha}$ & $\mathrm{GCA}^{\mathrm{a}}$ & $\mathrm{g}^{\mathrm{Ib}}$ & $\mathrm{g}^{\mathrm{Ma}}$ & $\mathrm{g}^{\mathrm{Mb}}$ \\
\hline Chester White & 1.38 & .13 & & .62 & \\
Duroc & -.14 & .03 & -1.03 & -.61 & -.74 \\
Hampshire & -.34 & -.07 & -1.63 & -.24 & -.45 \\
Yorkshire & .54 & -.10 & 0 & .22 & 0 \\
\hline
\end{tabular}

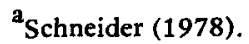

${ }^{\mathrm{b}} \mathrm{E} . \mathrm{R}$. Wilson and R. K. Johnson (unpublisbed manuscript).

below average. Hampshire also excelled in backfat and longissimus muscle area. Spot and Yorkshire were fatter than average and Chester White; Landrace and Spot were well below average in longissimus muscle area.

Relatively speaking, maternal effects were not large for carcass length, but they were quite large for backfat and longissimus muscle area. These analyses indicate that Spot and Yorkshire breeds excel in maternal effects on carcass merit. Additional data on maternal effects are presented below in the discussion of reciprocal differences.

It is useful to compare these estimates of breed direct and maternal effects with those presented by E. R. Wilson and R. K. Johnson (unpublisbed manuscript) and Schneider (1978), which are shown in table 16 . Some discrepancies are evident, but differences between the estimates probably have large standard errors.

\section{Crossbred Females}

From estimates of average individual and maternal genetic effects plus maternal heterosis effects, predictions can be made for the selection of crossbred females that can be expected to have superior reproduction traits. Based on least-squares constants for litter size (table 10), expectations are highest for crosses of Chester White, Lacombe, Yorkshire and Landrace.

In a comparison of the reproductive performance of sows from 28 crosses, Holtmann $e t$ al. (1975) found that Lacombe-Yorkshire and

TABLE 12. LEAST-SQUARES BREED OF SIRE $\left(\hat{\alpha}_{s}\right)$ AND BREED OF DAM $\left(\hat{\alpha}_{d}\right)$ EFFECTS FOR POSTWEANING GAIN (ADG) AND DAYS TO $100 \mathrm{KG}(\mathrm{AGE})^{\mathrm{a}}$

\begin{tabular}{|c|c|c|c|c|c|c|}
\hline \multirow[b]{2}{*}{ Breed $^{\mathrm{c}}$} & \multicolumn{3}{|c|}{$A D G, k g / d a y^{b}$} & \multicolumn{3}{|c|}{ AGE, days $s^{b}$} \\
\hline & $\hat{\alpha}_{\mathrm{s}}$ & $\hat{\alpha}_{\mathrm{d}}$ & $\hat{\alpha}_{s}+\hat{\alpha}_{d}$ & $\hat{\alpha}_{\mathrm{s}}$ & $\hat{\alpha}_{d}$ & $\hat{\alpha}_{s}+\hat{\alpha}_{\mathrm{d}}$ \\
\hline$\hat{\mu}$ & .67 & & & 179.7 & & \\
\hline $\mathbf{C}$ & $-.03 \pm .009$ & $-.03 \pm .008$ & -.06 & $7.7 \pm 1.7$ & $5.5 \pm 1.6$ & 13.2 \\
\hline $\mathbf{D}$ & $.02 \pm .006$ & $.02 \pm .006$ & .04 & $-3.2 \pm 1.0$ & $-3.2 \pm 1.1$ & -6.4 \\
\hline $\mathrm{H}$ & $-.00 \pm .007$ & $-.01 \pm .007$ & -.01 & $2.1 \pm 1.0$ & $2.1 \pm 1.2$ & 4.2 \\
\hline $\mathbf{L}$ & $.00 \pm .012$ & $-.00 \pm .012$ & .00 & $-1.6 \pm 2.3$ & $.1 \pm 2.3$ & -1.5 \\
\hline$\overline{\mathbf{P}}$ & $-.01 \pm .023$ & $-.00 \pm .023$ & -.01 & & & \\
\hline $\mathbf{S}$ & $.01 \pm .012$ & $.02 \pm .012$ & .03 & $-4.0 \pm 2.1$ & $-2.4 \pm 2.3$ & -6.4 \\
\hline$Y$ & $.00 \pm .006$ & $.01 \pm .006$ & .01 & $-1.0 \pm 1.0$ & $-2.0 \pm 1.1$ & -3.0 \\
\hline
\end{tabular}

${ }^{a}$ Experiments: Young et al. (1976b), Schneider (1977), Kuhlers et al. (1977), Kuhlers et al. (1972), L. K. Hutchens and R. K. Johnson (unpublisbed data). Model: experiment plus breed of sire plus breed of dam plus heterosis. Residual MS $=.025 \mathrm{~kg}^{2}$ (ADG) and 1,102 days ${ }^{2}$ (AGE), compared to literature averages of within breed variances of .005 and 224.5 .

${ }^{b}$ Breed of sire and breed of dam effects differ $(P<.01)$.

${ }^{c}$ See table 3 for identification of breeds. 
TABLE 13. DIRECT GENETIC ( $\left.\mathbf{g}^{\mathbf{I}}\right)$, GENERAL COMBINING ABILITY (GCA) AND MATERNAL EFFECTS $\left(g^{M}\right)$ ESTIMATED FOR DAYS TO $100 \mathrm{KG}$

\begin{tabular}{lrrrrr}
\hline Breed & $\hat{\alpha}_{\mathrm{s}}+\hat{\alpha}_{\mathrm{d}}$ & $\mathrm{GCA}^{\mathrm{a}}$ & $\mathrm{g}^{\mathrm{Ib}}$ & $\mathrm{g}^{\mathrm{Ma}}$ & $\mathrm{g}^{\mathrm{Mb}}$ \\
\hline Chester White & 13.2 & 3.4 & & 1.9 & -5 \\
Duroc & -6.4 & -2.7 & -5.5 & -3.1 & 1.7 \\
Hampshire & 4.2 & .2 & 3.5 & -.5 & 0 \\
Yorkshire & -3.0 & -.8 & 0 & -.5 & \\
\hline
\end{tabular}

${ }^{a}$ Schneider (1978).

${ }^{b_{E}}$. R. Wilson and R. K. Johnson (unpublisbed manuscript).

Hampshire-Landrace crosses farrowed and weaned the largest litters, and litters of crosses involving Yorkshire, Landrace and Lacombe were significantly larger than those involving Duroc, Hampshire, Berkshire and Large Black.

In further evaluations of specific mating systems, Fahmy and Holtmann (1977a) found litter size at birth to be above average for LandraceYorkshire, Hampshire-Landrace and DurocYorkshire crosses and below average for Large Black-Lacombe, Large Black-Landrace and Duroc-Lacombe crosses. Landrace-Yorkshire sows ranked highest in litter size at 21 days.
E. R. Wilson and R. K. Johnson ( unpublished data) compared crosses of Duroc, Landrace, Spot and Yorkshire breeding. Litter sizes at weaning were 7.58 for Duroc-Yorkshire, 7.82 for Duroc-Landrace, 7.31 for Duroc-Spot, 8.46 for Yorkshire-Landrace, 7.01 for Yorkshire-Spot and 7.58 for Landrace-Spot.

\section{Maternal Effects}

Maternal influences on different traits in swine have been reported (e.g., Pani et al., 1963; Robison, 1972). In most cases, the im-

TABLE 14. LEAST-SQUARES BREED EFFECTS FOR CARCASS TRAITS ${ }^{a}$

\begin{tabular}{|c|c|c|c|c|}
\hline Breed $^{b}$ & $\mathrm{n}$ & $\begin{array}{l}\text { Carcass } \\
\text { backfat, cm }\end{array}$ & $\begin{array}{l}\text { Longissimus } \\
\text { area, } \mathrm{cm}^{2}\end{array}$ & $\begin{array}{l}\text { Carcass } \\
\text { length, cm }\end{array}$ \\
\hline \multicolumn{5}{|c|}{ Breed of sire constants ${ }^{c}$} \\
\hline C & 131 & $.01 \pm .06$ & $-.83 \pm .59$ & $-.11 \pm .29$ \\
\hline D & 412 & $.02 \pm .04$ & $.55 \pm .41$ & $-.21 \pm .20$ \\
\hline $\mathbf{H}$ & 260 & $-.23 \pm .05$ & $1.84 \pm .48$ & $.52 \pm .23$ \\
\hline $\mathbf{L}$ & 38 & $.02 \pm .10$ & $-1.28 \pm .93$ & $.62 \pm .45$ \\
\hline $\mathbf{P}$ & 48 & $-.11 \pm .08$ & $1.02 \pm .82$ & $-.81 \pm .40$ \\
\hline $\mathbf{S}$ & 37 & $.15 \pm .10$ & $-.97 \pm .94$ & $-.65 \pm .46$ \\
\hline $\mathbf{Y}$ & 456 & $.14 \pm .04$ & $-.33 \pm .39$ & $.64 \pm .19$ \\
\hline \multicolumn{5}{|c|}{ Breed of dam constants ${ }^{c}$} \\
\hline C & 125 & $.01 \pm .06$ & $.06 \pm .59$ & $-.66 \pm .29$ \\
\hline $\mathbf{D}$ & 406 & $.09 \pm .04$ & $-1.44 \pm .04$ & $.01 \pm .19$ \\
\hline $\mathbf{H}$ & 253 & $-.12 \pm .05$ & $.74 \pm .48$ & $.36 \pm .23$ \\
\hline L & 45 & $.23 \pm .09$ & $-.90 \pm .90$ & $.52 \pm .43$ \\
\hline $\mathbf{P}$ & 48 & $-.13 \pm .08$ & $.64 \pm .82$ & $-1.27 \pm .40$ \\
\hline $\mathbf{S}$ & 33 & $-.05 \pm .10$ & $-.11 \pm .82$ & $.38 \pm .48$ \\
\hline $\mathbf{Y}$ & 472 & $-.03 \pm .04$ & $1.02 \pm .38$ & $.66 \pm .18$ \\
\hline
\end{tabular}

${ }^{a}$ Experiments: Young et al. (1976b); Schneider (1977); Kuhlers et al. (1977); Kuhlers et al. (1972); Bereskin et al. (1971); L. K. Hutchens and R. K. Johnson (unpublished data). Model: experiment plus breed of sire plus breed of dam plus heterosis.

$b_{\text {See table }} 4$ for identification of breeds.

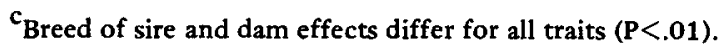


TABLE 15. DIRECT $\left(2 \hat{\alpha}_{s}\right)$ AND MATERNAL $\left(\hat{\alpha}_{d}-\hat{\alpha}_{s}\right)$ GENETIC EFFECTS FOR CARCASS TRAITS

\begin{tabular}{|c|c|c|c|c|c|c|}
\hline \multirow[b]{2}{*}{ Breed } & \multicolumn{3}{|c|}{ Direct genetic effect } & \multicolumn{3}{|c|}{ Maternal effect } \\
\hline & Length, cm & $\mathbf{B F}^{\mathbf{a}}, \mathrm{cm}$ & $\begin{array}{l}\text { Longissimus } \\
\text { area, } \mathrm{cm}^{2}\end{array}$ & Length, cm & $\mathrm{BF}^{\mathrm{a}}, \mathrm{cm}$ & $\begin{array}{l}\text { Longissimus } \\
\text { area, } \mathrm{cm}^{2}\end{array}$ \\
\hline Chester White & -.22 & .02 & -1.66 & -.55 & .00 & .89 \\
\hline Duroc & -.42 & .04 & 1.10 & .22 & .07 & -1.99 \\
\hline Hampshire & 1.04 & -.46 & 3.68 & -.16 & .11 & -1.10 \\
\hline Landrace & 1.24 & .04 & -2.56 & -.10 & .21 & .38 \\
\hline Poland & -1.62 & -.22 & 2.04 & -.46 & -.02 & -.38 \\
\hline Spot & -1.30 & .30 & -1.94 & 1.03 & -.20 & .86 \\
\hline Yorkshire & 1.28 & .28 & -.66 & .02 & -.17 & 1.35 \\
\hline
\end{tabular}

${ }^{\mathbf{a}} \mathbf{B F}=$ backfat.

portance of these effects has tended to diminish with age. Ahlschwede and Robison (1971a), however, reported that prenatal maternal effects contributed about $17 \%$ and postnatal maternal effects about $11 \%$ of the variance in postweaning growth and backfat. Also, Ahlschwede and Robison (1971b) reported that maternal sources of variation in 140-day weight were larger than direct genetic effects in both Duroc and Yorkshire. For Yorkshire, the maternal contribution was estimated to be 3.5 times as large as the direct genetic contribution for backfat, and correlations between direct and maternal genetic contributions were large and negative for both breeds.

Maternal effects on postweaning performance are also detectable through differences between reciprocal crosses, assuming that the samples of sires and dams representing each breed are of equal average genetic merit. Bereskin et al. (1971) reported large reciprocal differences between Duroc-Yorkshire crosses in backfat, longissimus muscle area and percentage ham and loin. Larger direct maternal effects of Yorkshire females were indicated.

Tables 17, 18 and 19 list differences between reciprocal crosses for growth rate, food conversion and carcass backfat. Reciprocal differences for growth rate are small and inconsistent, but large and consistent differences exist for food conversion and carcass backfat. Particularly interesting are those differences between crosses involving Yorkshire. In most cases, food conversion and carcass fat were better when Yorkshire was the dam. This is particularly evident for crosses of Yorkshire with Duroc and Hampshire.

The way in which this effect is mediated is

TABLE 16. DIRECT GENETIC ( $\mathrm{g}^{\mathrm{I}}$ ), GENERAL COMBINING ABILITY (GCA) AND MATERNAL EFFECTS $\left(\mathrm{g}^{\mathrm{M}}\right)$ FOR CHESTER WHITE, DUROC, HAMPSHIRE AND YORKSHIRE CARCASS TRAITS

\begin{tabular}{|c|c|c|c|c|c|c|c|c|}
\hline \multirow[b]{3}{*}{ Breed } & \multicolumn{4}{|c|}{ Direct genetic effect } & \multicolumn{4}{|c|}{ Maternal genetic effect } \\
\hline & \multirow{2}{*}{$\frac{\text { Length, } \mathrm{cm}}{\mathrm{GCA}^{2}}$} & \multicolumn{2}{|c|}{$\mathrm{BF}^{\mathrm{c}}, \mathrm{cm}$} & \multirow{2}{*}{$\begin{array}{l}\text { Longissimus } \\
\text { area, } \mathrm{cm}^{2} \\
\mathrm{GCA}^{\mathrm{a}}\end{array}$} & \multirow{2}{*}{$\frac{\text { Length, cm }}{\mathrm{a}}$} & \multicolumn{2}{|c|}{$\mathrm{BF}^{\mathrm{c}}, \mathrm{cm}$} & \multirow{2}{*}{$\begin{array}{l}\text { Longissimus } \\
\text { area, } \mathrm{cm}^{2}\end{array}$} \\
\hline & & $\mathrm{GCA}^{\mathrm{a}}$ & $g^{I b}$ & & & a & $\mathbf{b}$ & \\
\hline Chester White & -.56 & .10 & & -1.29 & -.15 & -.05 & & .84 \\
\hline Duroc & -.38 & .06 & .20 & 1.10 & .64 & -.02 & .22 & -1.87 \\
\hline Hampshire & .30 & -.24 & -.45 & 1.23 & -.30 & .12 & .33 & -.77 \\
\hline Yorkshire & .61 & .08 & .00 & -1.10 & -.19 & -.06 & .00 & 1.74 \\
\hline
\end{tabular}

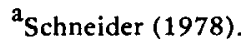

${ }^{b}$ E. R. Wilson and R. K. Johnson (unpublisbed manuscript).

$c_{B F}=$ backfat.
} 
TABLE 17. MATERNAL EFFECTS ON POSTWEANING PERFORMANCE: AVERAGE DAILY GAIN (KILOGRAMS)

\begin{tabular}{|c|c|c|c|c|c|c|}
\hline \multirow[b]{2}{*}{ Cross } & \multicolumn{6}{|c|}{ Experiment } \\
\hline & $\mathbf{a}$ & b & c & d & e & f \\
\hline CD-DC & .02 & & & & & \\
\hline $\mathrm{CH}-\mathrm{HC}$ & -.00 & & & & & \\
\hline CY-YC & .01 & & & & & \\
\hline DH-HD & -.02 & .02 & .00 & & & \\
\hline DY-YD & -.01 & .00 & -.01 & -.02 & & \\
\hline DL-LD & & & & -.04 & & \\
\hline DS-SD & & & & .02 & & \\
\hline HY-YH & .01 & .02 & -.03 & & & \\
\hline LY-YL & & & & -.01 & & \\
\hline LS-SL & & & & & & \\
\hline SY-YS & & & & -.02 & & \\
\hline SL-LS & & & & .02 & & \\
\hline PY-YP & & & & & .02 & -.01 \\
\hline
\end{tabular}

\footnotetext{
${ }^{a}$ Schneider (1978).

${ }^{b}$ Young et al. (1976b).

c Johnson et al. (1978).

$\mathrm{d}_{\mathrm{L}}$. K. Hutchens and R. K. Johnson (unpublished

$\mathbf{e}_{\text {Kuhlers } e t \text { al. (1972). }}$.

$\mathrm{f}_{\text {Kuhlers et al. (1977). }}$
} data).

not clear. Reciprocal crosses of Yorkshire with Hampshire and Duroc have been raised in litters of different sizes, but pig weights have been nearly identical. Postweaning daily food consumption, however, has been significantly less when pigs have been born from Yorkshire dams (Young et al., 1976b; Johnson et al., 1978).

It is possible that reciprocal crosses, although genetically equal, have similar weights but different compositions at weaning. This could result in different physiological demands for energy that alter postweaning food intake. This would also affect composition and efficiency of growth, but not necessarily rate of growth. This effect could be due to number of pigs per litter, composition of the dam's milk, a combination of both factors or perhaps some other, completely different factors. Fahmy and Holtmann (1977b) showed no appreciable differences between breeds in composition of colostrum, but milk from Yorkshire sows was above the overall mean in mineral, ash and energy content. In any event, reciprocal differences must be considered in comparisons of breeding systems.

\section{Crossbred Sires}

In the design of breeding programs, crossbred sires would be recommendec if the advantage obtained from paternal heterosis outweighed the loss that might be expected from recombination and the increased complexity in the general structure of the industry that might result.

Hauser et al. (1952) found that crossbred boars surpassed the parent lines in testis weight, epididymis weight and stage of spermatogenesis. Similarly, Wilson et al. (1977) and Neely et al. (1979) found that, at a constant age, crossbred boars had significantly larger testes and more total sperm than purebred boars. Wilson et al. (1977) also found significant differences between purebreds and crossbreds in ability to mate successfully with estrus females. Conception rates, although not significant, were $8 \%$ higher for crossbred boars. In an evaluation of purebred and crossbred boars of Duroc, Landrace, Spot and Yorkshire breeding, E. R. Wilson and $\mathrm{R}$. K. Johnson (unpublisbed data) found that crossbred boars had an advantage over purebreds in conception rate but that there were no differences in litter size and progeny performance. First-service conception rate was $75 \%$ for 376 females mated to 48 purebred boars and $83.9 \%$ for 243 females mated to 71 crossbred boars. Conception rates during an 8-week breeding period were 91.8 and $96.8 \%$ for purebred and crossbred boars, respectively. Crossbred boars averaged 1.22 services per conception, compared to 1.41 for purebreds. Litter size at birth was $\mathbf{1 0 . 1 0}$ for females mated to purebred boars and $\mathbf{1 0 . 0 1}$ for those mated to crossbred boars. Postweaning performance

\section{TABLE 18. MATERNAL EFFECTS ON POSTWEANING PERFORMANCE: FEED EFFICIENCY (GAIN TO FEED RATIO)}

\begin{tabular}{lrrrr}
\hline Cross & a & b & c & d \\
\hline DH-HD & -.011 & -.005 & & \\
DY-YD & .019 & .022 & & \\
HY-YH & .029 & .029 & & \\
PY-YP & & & -.04 & .01 \\
\hline
\end{tabular}

\footnotetext{
${ }^{\mathrm{a}}$ Young et al. (1976b).

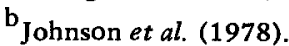

$c_{\text {Kuhlers et al, (1972). }}$

d Kuhlers et al. (1977).
} 
TABLE 19. MATERNAL EFFECTS ON POSTWEANING PERFORMANCE: CARCASS BACKFAT (CENTIMETERS)

\begin{tabular}{|c|c|c|c|c|c|c|c|}
\hline \multirow[b]{2}{*}{ Cross } & \multicolumn{7}{|c|}{ Experiment } \\
\hline & $\mathbf{a}$ & b & c & $\mathrm{d}$ & e & $\mathbf{f}$ & $\mathbf{g}$ \\
\hline CD-DC & & & & .04 & & & \\
\hline $\mathrm{CH}-\mathrm{HC}$ & & & & .17 & & & \\
\hline CY-YC & & & & -.01 & & & \\
\hline DH-HD & .06 & .04 & & .14 & & & \\
\hline DY-YD & -.22 & -.25 & -.89 & -.04 & -.34 & & \\
\hline DL-LD & & & .11 & & & & \\
\hline DS-SD & & & -.36 & & & & \\
\hline HY-YH & -.40 & -.27 & & -.18 & & & \\
\hline LY-YL & & & -.59 & & & & \\
\hline LS-SL & & & & & & & \\
\hline SY-YS & & & .05 & & & & \\
\hline SL-LS & & & .26 & & & & \\
\hline PY-YP & & & & & & .31 & -.15 \\
\hline
\end{tabular}

a Young et al. (1976b).

bohnson et al. (1978).

C. K. Hutchens and R. K. Johnson (unpublisbed data).

$\mathrm{d}_{\text {Schneider (1978). }}$

Bereskin et al. (1971).

$f_{\text {Kuhlers et al. (1972). }}$

$\mathbf{g}_{\text {Kuhlers et al. (1977). }}$

was essentially equal for progeny of the two groups.

These results agree with those of Schlote $e t$ al. (1974), Lishman et al. (1975) and Fahmy and Holtmann (1977a), who found litters produced by crossbred boars to be similar in size and weight to those produced by purebred boars.

Theoretically, progeny of crossbred boars are expected to be more variable than progeny of purebred boars. Several researchers (e.g., Rempel et al., 1964; Lishman et al., 1975; Fahmy and Holtmann, 1977a) found little differences in variability, and, in some cases, progeny of crossbred boars were less variable.

\section{Conclusion}

Large breed differences in direct and maternal genetic effects are evident for most traits. Individual heterosis is greatest for growth and survival traits, while crossbred females have a distinct advantage over purebreds in litter size and weight. These genetic differences suggest large economic differences among various crossing systems, differences that depend on the breeds involved and the percentage of the heterosis utilized by the system.

The economic advantage of crossbred boars appears to be derived from higher conception rates and fewer breeding problems, advantages that may be quite important. A $10 \%$ increase in first-service conception rate translates to about 210 maintenance days per 100 females in the breeding herd. Also, fewer breeding problems and more aggressive boars are economically important.

\section{Literature Cited}

Ahlschwede, W. T. and O. W. Robison. 1971a. Prenatal and postnatal influences on growth and backfat in swine. J. Anim. Sci. 32:10.

Ahlschwede, W. T. and O. W. Robison. 1971b. Maternal effects on weights and backfat of swine. J. Anim. Sci, 33:1206.

Bereskin, B., C. E. Shelby and L. N. Hazel. 1971. Carcass traits of purebred Durocs and Yorkshires and their crosses. J. Anim. Sci. 32:413.

Bichard, M. and W. C. Smith. 1972. Crossbreeding and genetic improvement. In D.J.A. Cole (Ed.) Pig Production. Pennsylvania State University Press, University Park.

Bradford, G. E., A. B. Chapman and R. H. Grummer. 1953. Performance of hogs of different breeds 
and from straightbred and crossbred dams on Wisconsin farms. J. Anim. Sci. 12:582.

Chambers, D. C. and J. A. Whatley. 1951. Heterosis in crosses of inbred lines of Duroc swine. J. Anim. Sci. 10:505.

Clark, J. R., N. L. First, A. B. Chapman and L. E. Casida. 1970. Age at puberty in four genetic groups of swine. J. Anim. Sci. 31:1032.

Craft, W. A. 1953. Results of swine breeding research. Circular No. 916, USDA.

Cunningham, P. J., M. E. England, L. D. Young and Dwane R. Zimmerman. 1979. Selection for ovulation rate in swine: Correlated response in litter size and weight. J. Anim. Sci. 48:509.

Dickerson, G. E. 1969. Experimental approaches in utilizing breed resources. Anim. Breed. Abstr. 37:191.

Dickerson, G. E. 1973. Inbreeding and heterosis in animals. In Proceedings of the Animal Breeding and Genetics Symposium in Honor of Dr. Jay L. Lush. ASAS, Champaign, IL.

Dufour, J. J. and M. H. Fahmy. 1975. Embryonic mortality and development during early pregnancy in three breeds of swine with purebred and crossbred litters. Can. J. Anim. Sci. 55:9.

Fahmy, M. H., C. S. Bernard and W. B. Holtmann. 1971. Crossbreeding swine: Reproductive performance of seven breeds of sows bred to produce crossbred progeny. Can. J. Anim. Sci. 51:361.

Fahmy, M. H. and W. B. Holtmann. 1977a. Evaluation of three- and four-breed cross litters and pigs sired by purebred and crossbred boars. Anim. Prod. 24:261.

Fahmy, M. H. and W. B. Holtmann. 1977b. Crossbreeding swine in Canada World Rev. Anim. Prod.

Foote, W. C., D. P. Waldorf, A. B. Chapman, H. L. Self, R. H. Grummer and L. E. Casida. 1956. Age at puberty of gilts produced by different systems of mating. J. Anim. Sci. 15:959.

Fredeen, H. T. 1957. Crossbreeding and swine production. Anim. Breed. Abstr. 25:339.

Hauser, E. R., G. E. Dickerson and D. T. Mayer. 1952. Reproductive development and performance of inbred and crossbred boars. Missouri Agr. Exp Sta. Bull. 503

Henderson, C. R. 1948. Estimation of general, specific and maternal combining abilities in crosses among inbred lines of swine. Ph.D. Thesis. Iowa State Univ., Ames.

Holtmann, W. B., M. H. Fahmy, T. M. MacIntyre and J. E. Moxley. 1975. Evaluation of female reproductive performance of twenty-eight one-way crosses produced from eight breeds of swine. Anim. Prod. 21:199.

Johnson, R. K. 1980 . Heterosis and breed effects in swine. North Central Regional Pub. No. 262.

Johnson, R. K., I. T. Omtvedt and L. E. Walters. 1978. Comparison of productivity and performance for two-breed and three-breed crosses in swine. J. Anim. Sci. 46:69.

Kuhlers, D. L., A. B. Chapman and N. L. First. 1972. Estimates of genotype-environment interactions in production and carcass traits in swine. $J$. Anim. Sci. 35:1

Kuhlers, D. L., A. B. Chapman and N. L. First. 1977. Estimates of genotype $X$ environment interactions with and between two breeds of swine for production and carcass traits. J. Anim. Sci. 44:549.

Lishman, W. B., W. C. Smith, M. Bichard and R. Thompson. 1975. The comparative performance of purebred and crossbred boars in commercial pig production. Anim. Prod. 21:69.

Lush, J. L., P. S. Shearer and C. C. Culbertson. 1939. Crossbreeding hogs for pork production. Iowa Agr. Exp. Sta. Bull. 380:83.

Neely, J. D., B. H. Johnson and O. W. Robison. 1979. Heterosis estimates for measures of reproductive traits in crossbred boars. J. Anim. Sci. 49(Suppl. 1): 11 .

Nelson, R. E. and O. W. Robison. 1976a. Comparisons of specific two- and three-way crosses of swine. J. Anim. Sci. 42:1150.

Nelson, R. E. and O. W. Robison. 1976b. Effects of postnatal maternal environment on reproduction of gilts. J. Anim. Sci. 43:71.

Otis, D. H. 1904. Experiments in feeding steers and breeding pigs. Kansas Agr. Exp. Sta. Bull. 124: 35 .

Pani, S. N., B. N. Day, L. F. Tribble and J. F. Lasley. 1963. Maternal influence in swine as reflected by differences in reciprocal crosses. Missouri Agr. Exp. Sta. Bull. 830 .

Rempel, W. E., R. E. Comstock and F. D. Enfield. 1964. Comparison of performance of crossbred pigs sired by purebred and crossbred boars. J. Anim. Sci. 23:87.

Robison, $O$. W. 1972. The role of maternal effects in animal breeding. $V$. Maternal effects in swine. J. Anim. Sci. 35:1303.

Robison, W. L. 1948. Crossbreeding for the production of market hogs. Ohio Agr. Exp. Sta. Res. Bull. 675 .

Schlote, W., M. Fender and D. Fewson. 1974. The Baden-Wurttemberg crossbreeding experiment in swine-preliminary evaluation. Proceedings of the Working Symposium on Breed Evaluation and Crossing. Experiments with Farm Animals. Zeist, Netherlands, p. 343-52.

Schneider, J. 1977. Heterosis, combining abilities and maternal ability estimated from single crosses among four breeds of swine. M.S. Thesis. Iowa State Univ., Ames.

Schneider, J. 1978. Individual and maternal heterosis estimated from single crosses and backcrosses of swine. Ph.D. Thesis. Iowa State Univ., Ames.

Sellier, P. 1976. The basis of crossbreeding in pigs: A review. Livestock Prod. Sci. 3: 203.

Smith, H. J. and J. B. McLaren. 1967. Performance of breeds and breed crosses of swine. Tennessee Agr. Exp. Sta. Bull 434

Sprague, G. F. and L. D. Tatum. 1942. General vs specific combining ability in single crosses of corn. J. Amer. Soc. Agron. 34:923.

Squires, C. P., G. E. Dickerson and D. T. Mayer. 1952. Influence of inbreeding, age and growth rate of sows on sexual maturity, rate of ovulation, fertilization and embryonic survival. Missouri Agx. Exp. Sta. Res. Bull. 494.

Young, L. D., R. K. Johnson and I. T. Omtvedt. 1976a. Reproductive performance of swine bred to produce purebred and two-breed cross litters. J. Anim. Sci. 42:1133.

Young, L. D., R. K. Johnson, I. T. Omtvedt and L. E. 
Walters. $1976 \mathrm{~b}$. Post-weaning performance and carcass merit of purebred and two breed cross pigs. J. Anim. Sci. 42:1124.

Whatley, J. A., Jr., D. Chambers and D. F. Stephens. 1954. Using hybrid vigor in producing market pigs. Oklahoma Agr. Exp. Sta. Bull. 415.

Wilson, E. R., R. K. Johnson and R. P. Wettemann. 1977. Reproductive and testicular characteristics of purebred and crossbred boars. J. Anim. Sci.
$44: 939$.

Winters, L. M., O. M. Kiser, P. S. Jordan and W. H. Peters. 1935. A six years study of crossbreeding swine. Minnesota Agr. Exp. Sta. Bull. 320.

Zimmerman, D. R., H. G. Spies, E. M. Rigor, H. L. Self and L. E. Casida. 1960. Effects of restricted feeding, crossbreeding and season of birth on age at puberty in swine. J. Anim. Sci. 19: 687. 